\title{
Miten lähi- ja luomuruoka erottuvat toisistaan ja muusta kotimaisesta ruoasta kuluttajan mielessä?
}

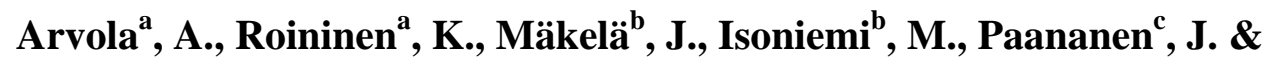 \\ Forsman-Hugg ${ }^{c}$, S.
}

a)VTT Biotekniikka, PL 1500, 02044 VTT, anne.arvola@vtt.fi; b) Kuluttajatutkimuskeskus, PL 5, 00531 Helsinki, johanna.makela@ncrc.fi, c) MTT Taloustutkimus, Luutnantintie 13, 00410 Helsinki, sari.forsman-hugg@mtt.fi

\section{Tiivistelmä}

Lähituotannon käyttäminen elintarvikkeiden markkinointikeinona edellyttää nykyistä parempaa tietoa siitä, minkälainen motivaatiopohja kuluttajilla on lähiruoan käyttöön. Onko lähituotannolla kuluttajalle lisäarvoa luomu- ja kotimaiseen tuotantoon verrattuna?

Kuluttajatutkimuskeskuksella, VTT Biotekniikalla ja MTT Taloustutkimuksella on käynnissä kolmivuotinen (2003 - 2005) yhteistyöhanke "Kuluttajat, päättäjät ja lähi- ja luomuruoka - mahdollisuuksia pk-sektorille”. Tutkimuksessa tavoitteena on selvittää mm., miten kuluttajat ja kunnalliset päätöksentekijät määrittelevät ja mieltävät lähiruoan ja miten lähiruoka heidän mielessään asemoituu suhteessa luomu- ja muuhun kotimaiseen ruokaan.

Tässä artikkelissa kuvataan kuluttajien mielikuvia koskevia tuloksia aineistosta, joka on kerätty koko Suomesta Internetkyselyllä vuonna 2004 (N=1 695). Tutkimuksen muut tulokset koskevat kuluttajien ja päättäjien määritelmiä lähiruoasta, lähi- ja luomuruoan tulevaisuusnäkymiä sekä kuntapäättäjien näkemyksiä lähi- ja luomuruoan käytön edellytyksistä ja vaikuttimista kunnissa.

Vastaajien mielikuvissa suurin ero oli kotimaisen ja ulkomaisen ruoan välillä. Sen sijaan lähi-, luomu- ja muu kotimainen ruoka erosivat toisistaan vain vähän. Kuluttajat liittivät sekä kotimaiseen luomu-, lähi- että muuhun kotimaiseen ruokaan mielikuvia, jotka kuvastivat luottamusta ja uskoa hyvään laatuun. Kaikkien kotimaisten vaihtoehtojen uskottiin myös edistävän (omaa, perheen, tulevien sukupolvien tai eläinten) hyvinvointia. Lähi- ja luomuruokaan nämä mielikuvat liittyivät kuitenkin hieman vahvemmin kuin muuhun kotimaiseen ruokaan. Sen sijaan ilmaisu "ulkomainen ruoka" herätti selvästi kielteisempiä mielikuvia.

Lähiruoka erottui muista ruokatyypeistä selkeästi vain kahdessa ominaisuudessa; oman kotiseudun yrittäjiä tukevana ja vaikeana tunnistaa kaupassa. Vaikka samoja uskomuksia liitettiin kaikkiin kotimaisiin vaihtoehtoihin, lähiruoka arvioitiin kuitenkin monessa suhteessa muuta kotimaista ruokaa "paremmaksi"; laadukkaammaksi, omaa, perheen tai eläinten hyvinvointia edistäväksi, luonnollisemmaksi, vähemmän teolliseksi, tuotannoltaan pienimuotoisemmaksi ja sen alkuperä helpommaksi jäljittää. Kotimaiseen verrattuna lähiruoan heikkouksia olivat heikon tunnistettavuuden lisäksi jossain määrin myös korkea hinta, huonompi saatavuus ja epätasaisempi laatu.

Lähi- ja luomuruokaan suhtauduttiin hieman eri tavoin paikkakunnasta riippuen. Pääkaupunkiseudulla ja Etelä-Suomessa lähiruokaan liitettiin kielteisempiä mielikuvia kuin muualla Suomessa. Naiset ja ruoan luonnollisuutta arvostavat näkivät lähi- ja luomuruoalla muita enemmän myönteisiä ominaisuuksia. Muutoin taustatekijöillä oli vain vähän yhteyttä uskomuksiin.

Asiasanat: kuluttajatutkimus, lähiruoka, luomuruoka, asenteet, mielikuvat 


\section{Johdanto}

Poliittisesta näkökulmasta lähiruoka nähdään mahdollisuutena maaseudun taloudellisen ja kulttuurisen elinvoimaisuuden edistämiseen ja säilyttämiseen (La Trobe ja Abott, 2000; Marsden ym., 2000). Kuluttajille lähiruoan uskotaan merkitsevän myös parempaa laatua ja varmuutta ruoan alkuperästä. Niin tutkijat kuin kuluttajatkin liittävät lähi- ja luomuruokaan osittain päällekkäisiä merkityksiä. Niiden mielletään esimerkiksi olevan enimmäkseen pienimuotoista ja perinteistä tuotantoa sekä tuovan myönteisiä ympäristö- sosiaalisia ja eettisiä vaikutuksia (esim. Gilg \& Battershill, 1998; Laaksonen ym., 2002; Seppälä ym., 2002).

Lähi- ja luomuruoan kuluttajalähtöinen markkinointi edellyttää nykyistä parempaa tietoa siitä, miten kuluttajat hahmottavat ne. Mistä syistä kuluttajat todellisuudessa olisivat kiinnostuneita lähiruoan käytöstä tai mistä syistä eivät? Onko lähituotannolla kuluttajalle lisäarvoa luomuun ja kotimaiseen tuotantoon verrattuna?

Kuluttajatutkimuskeskuksella, VTT Biotekniikalla ja MTT Taloustutkimuksella on käynnissä kolmivuotinen (2003 - 2005) yhteistyöhanke "Kuluttajat, päättäjät ja lähi- ja luomuruoka - mahdollisuuksia pk-sektorille”. Tutkimuksessa tavoitteena on selvittää mm., miten kuluttajat ja kunnalliset päättäjät määrittelevät ja mieltävät lähiruoan ja miten lähiruoka heidän mielessään asemoituu suhteessa luomuruokaan ja muuhun kotimaiseen ruokaan. Tavoitteena on tuottaa tietoa, joka voi edistää pienten ja keskisuurten kotimaisten elintarvikeyritysten mahdollisuuksia lähi- ja luomuruoan nykyistä selkeämpään tuotteistamiseen ja kohdistetumpaan markkinointiin.

Tässä artikkelissa kuvataan tuloksia vain tutkimuksen yhdestä kuluttajille suunnatusta kysymyssarjasta, joka koski kuluttajien mielikuvia ulkomaisesta ruoasta, kotimaisesta lähiruoasta, kotimaisesta luomuruoasta ja kotimaisesta ruoasta. Tutkimus on lisäksi tuottanut tietoa mm. siitä, miten kuluttajat ja kunnalliset päättäjät määrittelevät lähiruoan ja arvioivat lähi- ja luomuruoan tulevaisuudennäkymiä.

\section{Aineisto ja menetelmät}

Hankkeessa toteutettiin vuonna 2003 kolme laadullista tutkimusta, joiden tulosten perusteella rakennettiin yleistettäviin tuloksiin tähtäävät kuluttaja- ja päättäjäkyselyt vuonna 2004. Internet-pohjaiseen kuluttajakyselyyn saatiin vastauksia 1695 kappaletta. Vastaajat edustavat melko hyvin suomalaisia internetkäyttäjiä. Koko väestöön verrattuna tässä aineistossa vanhimmat ikäluokat, vain perusasteen koulutuksen saaneet ja/tai yksin asuvat ovat hieman aliedustettuina

Tässä artikkelissa kuvataan tuloksia kysymyssarjasta, jossa selvitettiin kuluttajien mielikuvia kotimaisesta ruoasta, kotimaisesta luomuruoasta, lähiruoasta ja ulkomaisesta ruoasta 34 väittämän avulla. Vastaajia pyydettiin arvioimaan kunkin väittämän kohdalla, kuinka hyvin se sopii hänen mielikuvaansa em. neljän tyyppisestä ruoasta (asteikko 1 - 5). Faktorianalyysien pohjalta osa väittämistä yhdistettiin keskiarvomuuttujiksi (jäljempänä merkintä km).

Mielikuvien eroja lähi-, luomu- ym. ruokien välillä selvitettiin keskiarvotesteillä sekä erotteluanalyyseilla. Erotteluanalyysiä käytettiin selvittämään, mitkä mielikuvien ulottuvuudet kaikkein keskeisimmin erottavat ja yhdistävät tutkittuja ruokatyyppejä.

Tämän lisäksi selvitettiin, onko mahdollista kuvailla minkälainen kuluttaja pitää lähiruokaa parempana kuin kotimaista ruokaa. Tätä tarkasteltiin laskemalla kustakin uskomusmuuttujasta jokaiselle vastaajalle uudet eromuuttujat, jotka kuvaavat sitä miten paljon lähiruokaa koskeva uskomus eroaa vastaavasta kotimaista ruokaa koskevasta uskomuksesta ko. vastaajan kohdalla. Näiden muuttujien keskiarvoja tarkasteltiin tämän jälkeen varianssianalyyseillä eri taustatekijöiden mukaisissa ryhmissä sekä erotteluanalyysillä. Erotteluanalyysillä selvitettiin, miten eroavat lähiruokaa eniten kotimaiseen ruokaan verrattuna parempana ja vähiten parempana pitävät vastaajat. Viimeksi mainituista tuloksista tässä artikkelissa on esitetty vain yhteenveto.

\section{Tuloksia}

\section{Mielikuvat lähi-, kotimaisesta luomu-, kotimaisesta ja ulkomaisesta ruoasta koko vastaajajoukossa}

Suurin ero kuluttajien mielikuvissa on kotimaisen ja ulkomaisen ruoan välillä. Sen sijaan lähi-, luomu- ja muu kotimainen ruoka eroavat toisistaan vain vähän. Erotteluanalyysissä useimmat muuttu- 
jista latautuivat voimakkaasti ensimmäiselle erottelevalle ulottuvuudelle (selitysosuus 78 \%), joka erotti selvästi ulkomaisen ruoan kotimaisista vaihtoehdoista (kuva 1.). Kuluttajat liittivät sekä kotimaiseen luomu-, lähi- että muuhun kotimaiseen ruokaan mielikuvia, jotka kuvastivat luottamusta ja uskoa hyvään laatuun. Kaikkien kotimaisten vaihtoehtojen uskottiin myös edistävän (omaa, perheen, tulevien sukupolvien tai eläinten) hyvinvointia. Lähi- ja luomuruokaan nämä mielikuvat liittyivät kuitenkin hieman vahvemmin kuin muuhun kotimaiseen ruokaan. Sen sijaan ilmaisu "ulkomainen ruoka" herätti selvästi kielteisempiä mielikuvia. (Taulukko 1.)

Toinen erottelufunktio (selitysosuus $14 \%$ ) erotteli kotimaisen ruoan muista ruokatyypeistä. Suhteessa kotimaiseen luomuruokaan, lähiruokaan ja/tai ulkomaiseen ruokaan kotimaista ruokaa pidettiin paremmin saatavissa olevana, parempana Suomen kansantaloudelle, edullisempana sekä luotettavampana.

Kolmannen erottelufunktion (selitysosuus 7 \%) mukaan lähiruoka erottui muista ruokatyypeistä oman kotiseudun yrittäjiä tukevana, vaikeana tunnistaa kaupassa, sekä suhteessa luomuun edullisempana ja vähemmän luonnollisena.

Ulkomaisen, lähi-, luomu ja kotimaisen ruoan sijoittuminen erottelufunktioille 1 ja 2 .

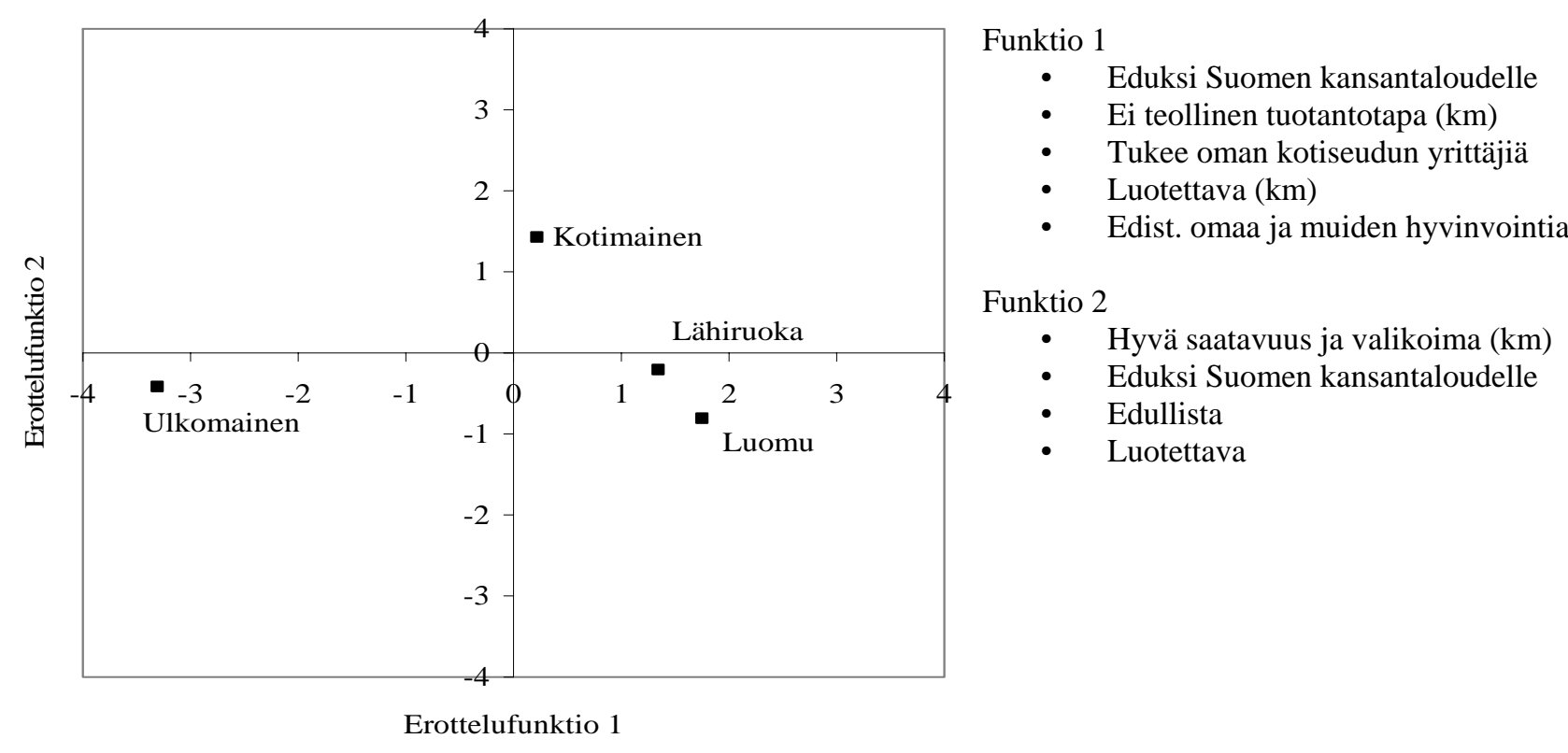

Kuva 1. Ulkomaisen, lähi-, kotimaisen luomu- ja kotimaisen ruoan sijoittuminen erottelufunktioille 1 ja 2. Ensimmäinen erotteluanalyysi.

Toisessa erotteluanalyysissä selvitettiin oleellisimpia eroja kotimaisten ruokatyyppien välillä (ulkomainen ruoka jätettiin pois analyysistä). Kuten ensimmäisessäkin analyysissä, lähiruoka miellettiin kotimaiseen ja luomuruokaan verrattuna vaikeammaksi tunnistaa kaupassa, paremmin oman kotiseudun yrittäjiä tukevaksi, sekä luomuruokaan verrattuna vähemmän luonnolliseksi. Keskiarvojen tarkastelu ruokatyyppien välillä kuitenkin osoittaa lähi- ja luomuruoan eroavan myönteisesti muillakin tavoilla - erot vain ovat usein pieniä. Kotimaiseen verrattuna lähiruoka näyttäytyy vähemmän teollisena ja teknologisena, perinteisemmin ja pienimuotoisemmin tuotettuna (taulukko 1.). 
Lähi-, luomu ja kotimaisen ruoan sijoittuminen erottelufunktioille 1 ja 2 .

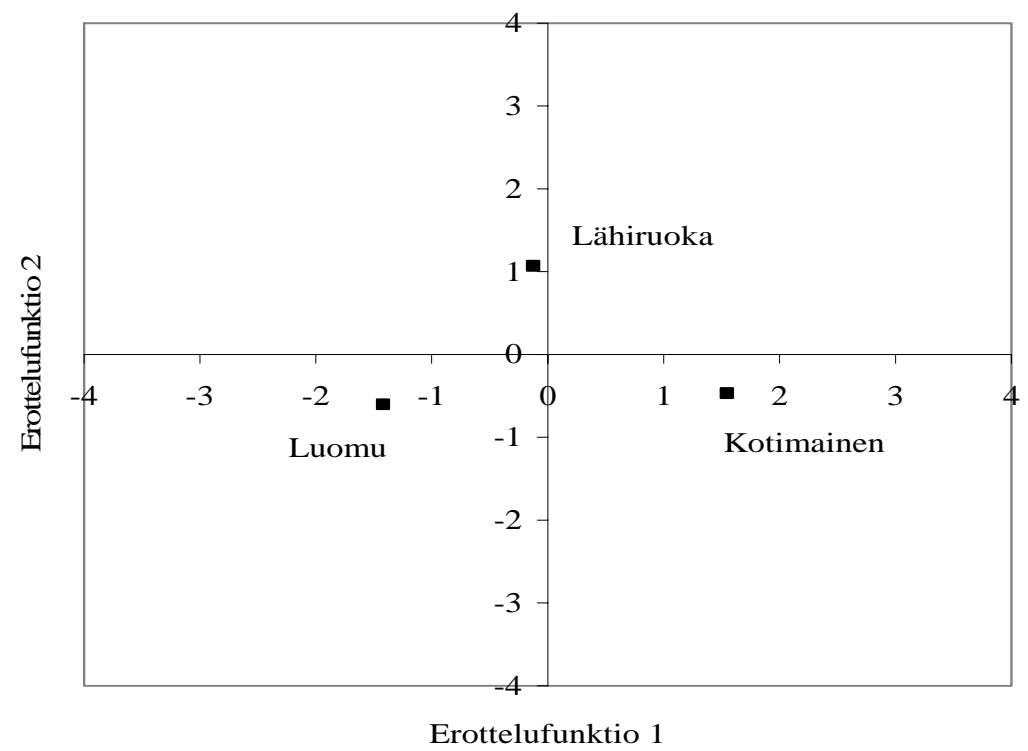

Funktio 1

- Hyvä saatavuus ja valikoima $(\mathrm{km})$

- $\quad$ Teollinen valmistus $(\mathrm{km})$

- $\quad$ Edullista

Funktio 2

- Vaikea tunnistaa kaupassa

- Tukee oman kotiseutuni yrittäjiä

- Luonnollista, lisäaineetonta (km)

Kuva 2. Lähi-, kotimaisen luomu- ja kotimaisen ruoan sijoittuminen erottelufunktioille 1 ja 2. Toinen erotteluanalyysi, josta ulkomainen ruoka jätetty pois.

\section{Kuluttajaryhmien välisiä eroja mielikuvissa}

Lähi- ja luomuruoan tuotteistamisen ja markkinoinnin kannalta on kiinnostavaa tietää minkälaiset kuluttajat mieltävät nämä ruoat erilaisina kotimaiseen ruokaan verrattuna. Useimmista taustatekijöistä riippumatta (kaikenlaiset) kuluttajat olivat samaa mieltä siitä, että lähiruoka tukee oman paikkakunnan yrittäjiä paremmin kuin muu kotimainen ruoka, ja että se on kaupassa vaikeammin tunnistettavissa. Sen sijaan uskomukset, joiden voidaan tulkita kuvaavan lähiruoan hyödyllisyyttä tai paremmuutta kotimaiseen ruokaan nähden, erosivat joidenkin taustatekijöiden suhteen. Luonnollista ruokaa arvostavat naiset näyttävät olevan selkeimmin potentiaalinen kohderyhmä sekä lähi- että luomuruoalle, sillä nämä ryhmät kokevat todennäköisemmin lähi- ja luomuruoan tavanomaista kotimaista ruokaa paremmaksi. Jos kiinnitetään huomio erityisesti niihin uskomuksiin (luottamus, laatu ja hyvinvointivaikutukset), jotka parhaiten ennustivat lähi- ja luomuruoan käyttöaikomuksia, voidaan karkeasti ottaen sanoa, että potentiaalisimmat lähiruoan asiakkaat ovat naisia ja muuta kuin sekaruokaa syöviä ja/tai muualla kuin pk-seudulla asuvia. Vastaavasti todennäköisimmät luomuruoan ostajat olisivat myös muuta kuin sekaruokavaliota noudattavia naisia, yhtä hyvin keski-ikäisiä kuin nuoriakin.

Lähi- ja luomuruokaan suhtaudutaan kuitenkin hieman eri tavoin paikkakunnasta riippuen. Kun tarkastellaan vastakkain pääkaupunkiseutua ja muuta Suomea, nähdään, että pääkaupunkiseutulaisilla on enemmän motivaatiopohjaa luomu- kuin lähiruokatuotteiden käyttöön ja muualla Suomessa asuvilla erityisesti lähiruoan käyttöön. Tarkempi asuinpaikan mukainen tarkastelu osoittaa kuitenkin, että jako voi olla liian yksinkertaistettu. Esimerkiksi helsinkiläiset erottuvat muista pääkaupunkiseutulaisista hieman myönteisimmillä mielikuvillaan lähiruoasta. 
Taulukko 1. Yhteenveto tutkittujen ruokatyyppien eroista ja yhtäläisyyksistä kuluttajien mielikuvissa. Perustuu sekä keskiarvo- että erotteluanalyyseihin.

Kaikelle kotimaiselle ruoalle yhteistä.

Seuraavissa suhteissa tavanomainen, luomu, lähiruoka eivät erotu kuluttajien mielissä keskimäärin

- Luotettavuus ja turvallisuus $(\mathrm{km})$

- Tuotteesta saa halutessaan lisätietoja

- Eduksi Suomen kansantaloudelle

- Hyvä laatu (=hyvä maku, tuoreus, korkealaatuiset raaka-aineet) (tosin lähi- ja luomu hieman parempi. Luomu parempi raaka-aineiden laadussa, lähiruoka tuoreudessa)

Lisäksi kaikille kotimaiselle yhteistä, vaikka lähi- tai luomuruoka erottuu hieman:

- Tukee oman kotiseudun yrittäjiä

- Ei kovin teollista (teollinen =on vaikea tietää mistä tuote tulee, käytetty vähemmän perinteisiä menetelmiä, harvemmin pienyrityksessä valmistettu)

- Melko luonnollista ja vähän lisä- säilöntäaineita tai jäämiä sis.

Lähiruoka erottuu selkeimmin kotimaisesta ja luomuruoasta seuraavasti:

- Vaikeampi tunnistaa kaupassa

- Tukee paremmin oman kotiseutuni yrittäjiä

Lähiruoka (ja usein myös luomuruoka) kotimaiseen verrattuna vähän

- Luonnollisempaa ja puhtaampaa (km)

- Parempi laatu $(\mathrm{km})$

- Edistää paremmin omaa, eläinten ym. hyvinvointia $(\mathrm{km})$

- Tukee oman kotiseudun yrittäjiä

- Lisää vähemmän ympäristön kuormitusta

- On harvemmin uuden teknologian avulla valmistettua

- Vähemmän teollista ja perinteisemmin valmistettua $(\mathrm{km})$

- Laadultaan epätasaisempaa

- Vaikeampi tunnistaa kaupassa

- Kalliimpaa

- Huonompi saatavuus ja valikoima

Luomuruoka (kotimainen) erottuu lähiruoasta ja kotimaisesta ruoasta seuraavasti:

- Vähemmän teollisesti tuotettu $(\mathrm{km})$

- Luonnollisempaa ja puhtaampaa $(\mathrm{km})$

- Lisää vähemmän ympäristön kuormitusta

- Edistää enemmän omaa, perheen, eläinten ja/tai tulevien sukupolvien hyvinvointia $(\mathrm{km})$

Ulkomainen ruoka kotimaiseen (tavanomaiseen, lähi- tai luomuruokaan verrattuna) mielletään:

- Vähemmän luotettavaksi (km)

- Teollisemmaksi (=on vaikea tietää mistä tuote tulee, käytetty vähemmän perinteisiä menetelmiä, harvemmin pienyrityksessä valmistettu)

- Vähemmän luonnolliseksi (=enemmän jäämiä, lisäaineita, vähemmän vitamiineja, ei yhtä luonnollisesti tuotettua)

- Edullisemmaksi

- Lisää enemmän ympäristön kuormitusta 


\section{Yhteenveto ja johtopäätöksiä}

Pyydettäessä kuluttajia arvioimaan ulkomaista, kotimaista, kotimaista luomuruokaa ja lähiruokaa erilaisten ominaisuuksien suhteen, esille nousee voimakkaimmin erottelu ulkomaiseen ja kotimaiseen. Ulkomainen ruoka mielletään stereotyyppisesti huonommaksi ja kotimainen paremmaksi; luotettavaksi, turvalliseksi ja hyvälaatuiseksi. Mielikuvat kotimaisesta, lähi- ja luomuruoasta ovat melko samankaltaisia.

Lähiruoka erottuu siis luomuruoasta ja tavanomaisesta kotimaisesta ruoasta kuluttajien mielissä varsin huonosti; erityisesti vain siltä odotettuina myönteisinä aluetaloudellisina vaikutuksina sekä kaupassa huonosti tunnistettavana. Tutkimuksen kokonaistulosten perusteella voidaan päätellä, että lähiruoka on monille kuluttajille varsin jäsentymätön ja tuntematonkin käsite. Vaikka lähiruoalla ei koeta olevan monia ainutlaatuisia ominaisuuksia, sitä kuitenkin pidetään monessa suhteessa vähän parempana tavanomaiseen kotimaiseen ruokaan verrattuna. Kuluttajat liittävät sekä luomu- että lähiruokaan paljon samanlaisia ominaisuuksia kuten pienimuotoinen, perinteinen, ei-teollinen tuotantotapa sekä terveellisyys ja hyvä laatu. Näitä mielikuvia on lähiruokaan liitetty aikaisempienkin tutkimusten perusteella (Leipämaa, 2002), mutta aiemmin ei ole tarkasteltu eroja muihin ruokatyyppeihin.

Lähiruokaan verrattuna luomuruoka vaikuttaa kuluttajille jo selvemmin jäsentyneeltä käsitteeltä. Tulos oli sikäli odotettu, että luomutuotannolle ja -ruoalle on olemassa selkeät EU-säännökset. Merkillepantavaa on esimerkiksi, että luomuruoan tunnistamista kaupassa ei pidetä ongelmana, ja sitä pidetään luotettavana ja turvallisena. Tulokset ovat johdonmukaisia monissa aiemmissa tutkimuksissa (esim. Arvola \& Lähteenmäki, 2003; Bähr ym., 2004) saatujen tulosten kanssa siinä, että luomu erottuu tavanomaisesti tuotetusta ruoasta kalliimpana, luonnollisempana (puhtaampana, vähemmän jäämiä sisältävänä, vitamiinipitoisempana), hyvälaatuisena, sekä myönteisillä vaikutuksilla ihmisten, eläinten, tulevien sukupolvien ja ympäristön hyvinvointiin.

Suhtautumisessa lähiruokaan havaittiin selviä alueellisia eroja. Erityisesti pääkaupunkiseudulla tai Etelä-Suomessa lähiruokaan luotettiin vähemmän ja sitä pidettiin vähemmän luonnollisena ja puhtaana kuin muualla Suomessa. Tämä on ymmärrettävää kun ottaa huomioon, että lähiruoka määriteltiin paljolti maantieteellisen läheisyyden perusteella (tuloksia määritelmistä ei ole raportoitu tässä yhteydessä).

Tuloksia tulkittaessa on hyvä huomioida, että kuluttajien mielikuvia on selvitetty yleistermeistä "kotimainen ruoka", "ulkomainen ruoka", "kotimainen luomuruoka" ja "lähiruoka" sekä niistä annettuja lyhyiden määritelmien avulla. Vastaajat eivät siis reagoineet todellisiin tuotteisiin tai tuoteesimerkkeihin vaan vastasivat vain yleistermien herättämien mielikuvien perustella. Todellisessa valintatilanteessahan tuotepaketin päällä ei yleensä lue "lähiruoka" tai "ulkomainen ruoka". Tässä tutkimuksessa esiin tulleiden luokittelujen tai muiden lähiruokaan liittyvien mielikuvien (esim. lyhyt jakeluketju, aitous) aktivoituminen kuluttajan mielessä riippuu siitä, miten hän tulkitsee tuotteen näkyviä ominaisuuksia ja pakkausmerkintöjä vihjeiksi näistä asioista.

Tutkimusten tulosten perusteella lähiruokakäsitteen selkiyttäminen ja profilointi näyttäisi tarpeelliselta sen hyödyntämiseksi pienyritysten kilpailukeinona.

\section{Kirjallisuus}

Arvola, A., \& Lähteenmäki, L. (2003). Kuluttajien mielikuvat jalostetuista luomutuotteista. Tietoa markkinalähtöisen tuotekehityksen pohjaksi. (No. 2217). Espoo: VTT Biotekniikka.

Bähr, M., Botschen, M., Laberenz, H., Naspetti, S., Thelen, E., \& Zanoli, R. (2004). The European Consumer and Organic Foos (Vol. 4). Ceredigion: School of Management and Business, University of Wales Aberystwyth.

Gilg, A., \& Battershill, M. (1998). Quality farm food in Europe: a possible alternative to the industrialised food market and to current agri-environmental policies: lessons from France. Food Policy, 23(1), 25-40.

Laaksonen, P., Laaksonen, M., \& Leipämaa, H. (2002). Consumers' Orientation to Food and Eating (Raportti Tutkimuksia No. 243). Vaasa: Vaasan Yliopisto.

LaTrobe, H. L., \& Acott, T. G. (2000). Localising the global food system. International Journal of Sustainable Development and World Ecology, 7, 309-320.

Leipämaa, H. (2002). Lähiruoka osana jokapäiväistä ruokailua (Pro gradu tutkielma). Vaasa: Vaasan Yliopisto Kauppatieteellinen tiedekunta Markkinoinnin laitos. 
Mardsen, T., Banks, J., \& Bristow, G. (2000). Food Supply Chain Approaches: Exploring their Role in Rural Development. Sociologia Ruralis, 40(4), 425-438.

Seppälä, A., Voutilainen, P., Mikkola, M., Mäki-Tanila, A., Risku-Norja, H., Soini, K., et al. (2002). Ympäristö ja eettisyys elintarviketuotannossa - todentamisen ja tuotteistamisen haasteet (raportti No. MTT:n selvityksiä 11). Jokioinen: MTT. 